Secondary school pupils' satisfaction with their ability grouping placements

Susan Hallam and Judith Ireson, Institute of Education, University of London

Contact: Susan Hallam, Institute of Education, University of London, 20 Bedford Way, London WC1H OAL

Phone 02076126371

Fax 02076126766

E-mail s.hallam@ioe.ac.uk or shallam@globalnet.co.uk 


\title{
Secondary school pupils' satisfaction with their ability grouping placements
}

\begin{abstract}
There has been little research exploring pupils' satisfaction with their ability group placement. This paper explores the extent to which pupils are happy with their placement, and the reasons they give for wanting to move to another class or set. The sample comprised over 5,000 year 9 pupils (aged 13-14 years) in 45 mixed secondary comprehensive schools in England. The schools represented three levels of ability grouping in the lower school (years 7 to 9). Pupils responded to a questionnaire which explored their current set placement, their satisfaction with it, and their reasons for wanting to change. A substantial proportion of pupils expressed a wish to change set, most, but not all, in an upward direction, mainly because the level of work was inappropriate. The implications for ability grouping practices in schools are discussed.
\end{abstract}




\section{Secondary school pupils' satisfaction with their ability grouping placements}

\section{Introduction}

Although the evidence suggests that structured ability grouping, of itself, does not lead to consistently better or worse attainment for any particular group of pupils (for reviews see Hallam, 2002, Ireson and Hallam, 2001; Sukhnandan and Lee, 1998; Harlen and Malcolm, 1997) most secondary schools in the UK adopt some form of structured ability grouping, usually setting, for at least some subjects. (Benn and Chitty, 1996). The impact of such structured grouping systems on the social and personal outcomes for particular groups of children has been well documented with lower attaining pupils typically becoming stigmatized, disaffected and alienated from school (for reviews see Hallam, 2002; Ireson and Hallam, 2001; Sukhnandan and Lee, 1998; Harlen and Malcolm, 1997). There is also evidence that inaccurate placement in groups influences pupils' subsequent attainment. Barker Lunn (1970) found that the attainment of pupils who moved into higher streams improved while those of similar ability in lower streams deteriorated, while Ireson et al. (2002) found that pupils with similar prior attainment placed in different groups made differential progress. Those in a high, as opposed to a low or middle set made better progress. Placement in a low group also limits the opportunities to take higher papers in the tiered examinations at Key Stage 3 and GCSE.

Given that set placement can have such important consequences for individual pupils it is a matter for concern that allocation to sets or streams is a somewhat arbitrary affair and is not based entirely on prior academic achievement or ability (Jackson, 1964, Neave, 1975). Barker 
Lunn (1970), studying primary schools, showed that $15 \%$ of children were in the wrong stream at the end of the school year on the basis of English and arithmetic performance. This percentage was lower in the early primary years and higher in the later years. At the beginning of the next school year, on average a quarter of these children were moved into their correct stream, but three quarters remained in the wrong stream given their test performance. Troman (1988) found that for most pupils there was consensus between test results and teachers' perceptions and judgements and group allocation was unproblematic. Where this was not the case, teachers tended to rely on their perceptions of pupils, taking into account prior performance, prior performance of siblings, previous grouping allocation and even pupils' physical appearance. Pallas et al., (1994) found that first grade reading placements did not appear to be based on children's background characteristics, neither were they closely linked to children's academic performance or potential. Ability group placements resulted from the interaction of individual student characteristics with school organizational processes and constraints. Once placed in a group this can heighten inequalities in childrens' academic achievement over a period of several years (Dreeben \& Barr, 1988; Reuman, 1989). Recent evidence at primary and secondary level indicates that while most UK schools use internal tests, examinations, National Key Stage tests and standardised tests such as the Cognitive Abilities tests to allocate pupils to groups, in some cases behaviour and pupil motivation can influence set placement. Where schools try to separate disruptive pupils this can lead to inappropriate set placement for some (Ireson et al., 2002; Davies et al., 2003). Gender can also be a factor in ensuring the formation of balanced groups. 
There is extensive evidence that grouping allocation procedures are biased against some groups of children. Lower ability groups tend to include disproportionate numbers of children of low socio-economic status (Jackson, 1964; Sandven, 1971; Winn and Wilson, 1983; Oakes, 1985; Burgess, 1986; Vanfossen et al., 1987; Peak and Morrison, 1988; Taylor, 1993; Boaler, 1997a, b). Ethnic minorities also tend to be over represented (Winn and Wilson, 1983; Oakes, 1985; Burgess, 1986; Tomlinson, 1987; Wright, 1987; Commission for Racial Equality, 1992; Troyna and Siraj-Blatchford, 1993) as are children born in the summer. The latter are also more likely to be identified as having special educational needs (Wilson, 2000).

In the USA, students sometimes have a degree of choice regarding the track that they will pursue, academic, general or vocational. Where schools consult pupils about their preferred track, other information is also taken into account. While this would appear to overcome some of the difficulties outlined above, pupils' views of themselves are inevitably influenced by others attitudes. Qualitative studies suggest that race and social class influence secondary school placement over and above achievement because students from different backgrounds receive different information, advice and attention from counsellors and teachers (Cicourel \& Kitsuse, 1963; Oakes et al., 1992). Parents also lobby schools to get their children higher school placements (Oakes et al.1992).

Although the importance of students being able to move sets is stressed for the successful operation of structured grouping systems (Ofsted, 1998), in practice, there is very little movement (Barker Lunn, 1970; Dentzer \& Wheelock, 1990, Peak \& Morrison, 1988; Rist, 1970; Devine, 1993; Taylor, 1993; Troyna, 1992; CRE, 1992; Gillborn and Youdell, 2000). Recent UK studies have shown that, generally, schools do not keep detailed records of pupils' movements between groups (Ireson et al, 2002a; Davies et al, 2003). Even when teachers are 
aware that pupils are wrongly allocated they may not be moved to another group (Barker Lunn, 1970; Troyna, 1992). One problem is that there is often a gap between work that has been undertaken and what is required for the higher set (Jackson, 1964; Ireson and Hallam, 2001). A further problem is that in order to move some pupils to a higher set others have to move down (Ireson and Hallam, 2001; Davies et al., 2003). These issues apply in a similar manner in primary and secondary schools. At secondary school, where some subjects are taught on a carousel basis there may also be timetabling difficulties (Ireson and Hallam, 2001).

Little research has directly explored pupils' perceptions of their ability group placement. Hallam et al. (2004) showed that at primary level pupils were very aware of the grouping structures operating within their schools and the ways that they were allocated to particular groups. When asked about their satisfaction with their group placement, $55 \%$ of pupils indicated that they were happy, $26 \%$ wanted to move to a higher group, $12 \%$ to be with friends, $2 \%$ to a lower group, and $5 \%$ to be with a particular teacher. The pupils perceived that it was possible to change groups but that this was not easy. Parental pressure was seen as one method of effecting a change.

At secondary level Boaler, (1997a; 1997b; 1997c; Boaler et al., 2000) researched the experiences of pupils studying mathematics in two contrasting grouping systems, mixed ability and setted. Eighty three percent of the students interviewed in the setted classes wanted either to return to mixed ability teaching or to change set. This dissatisfaction was not restricted to those in the lower sets. Some of the students taught in the highest sets (Boaler 1997b) felt disadvantaged because they found it difficult to cope with the fast pace of the lessons and the pressures of consistently working at a high level. Particularly vulnerable were girls who wanted to acquire a deep understanding of mathematics who found this impossible 
in an environment where the pace of work did not allow for time for consolidation. These girls reported wanting to move to a lower set. The boys also reported adverse effects of the pressure in the higher sets, but they tended to not want to move to a lower set (Boaler et al, 2000).

The research reported here is part of a larger study which explored the academic, personal and social outcomes for pupils in 45 schools adopting either mixed ability, high levels of structured ability grouping or a combination of mixed or structured groupings. This paper reports the findings from questions exploring pupils' satisfaction with their group placement in mathematics, science and English, whether they would like to change group, and the reasons for wanting to change.

\section{Method}

\section{The school sample}

A stratified sample of 45 mixed gender secondary comprehensive schools was selected for the study, representing a range of grouping practices, intake and location. A variety of locations were represented, spreading from London and the Southern counties of England to East Anglia and South Yorkshire.

The sample comprised three levels of ability grouping in the lower secondary school (Years 7 to 9), with 15 schools at each level:

'Mixed Ability Schools' predominantly mixed ability classes for all subjects, with setting in no more than two subjects in Year 9. 
'Partially Set Schools' setting in no more than two subjects in Year 7, increasing to a maximum of 4 subjects in Year 9 .

'Set Schools'

streaming, banding or setting in at least four subjects from Year 7.

All schools had received satisfactory inspection reports during the three years before the start of the project. Steps were taken to balance the three groups of schools in terms of their size and the social mix of their intake, using free school meals as an indicator of social disadvantage. The mixed ability schools had a slightly more socially disadvantaged intake than the set Schools. On average, the set schools were slightly smaller than the other two groups. There was good overlap across groups for both distributions.

\section{Procedures}

Within the schools, the cohort of year 9 pupils was included in the sample. Key Stage 2 tests were taken by the cohort of pupils when in year 6 , the final year of primary school. Data on gender, ethnic origin, attendance and whether pupils were eligible for free school meals were collected from school records. Key Stage 3 test marks in English, mathematics and science were also collected. Detailed information about the setting arrangements in year 9 was collected from interviews with school managers and from heads of department.

Pupils were asked to complete a questionnaire that consisted of self-concept scales (Marsh, 1990), measures of attitudes towards school, and open ended questions regarding their preferences for particular types of pupil grouping, their grouping placements and their satisfaction with those placements. The questionnaire was completed by the pupils during lessons. Teachers or researchers assisted any pupils who had difficulties reading the 
questionnaire. This paper focuses on pupils' responses to questions regarding their satisfaction with their set placement, whether they wanted to change set, and if so in which direction and why. For each of three subjects, mathematics, English and science, pupils were asked: Which class or set are you in for mathematics/English/science? If you could choose would you like to be in a difference class or set for mathematics/English/science? If you answered YES, which class or set would you like to be in? Why would you like to be in that class or set?

The level of setting in each subject varied with some schools adopting rigorous setting from year 7 while others retained mixed ability grouping or used broad ability groups. A five-point scale was constructed to indicate the amount of setting experienced by each pupil in each subject during years 7, 8 and 9. A score of 4 was given when pupils were set in years 7-9 and rigorously in year 9, a score of 3 when pupils were set in years 7-9 and broadly in year 9, a score of 2 when they were set in years 8 and 9, a score of 1 when set in year 9 only and zero where classes were entirely mixed ability. This gave an indication of each pupils' experience of setting. In addition, because the number of sets varied between schools, pupils were assigned to a set category: lower, middle, or upper. These categories were based on proportions of children, $25 \%$ each for the lower and upper categories and $50 \%$ for the middle. In this way set placement could be compared across schools with different year group sizes and with different setting patterns. The number of schools setting for each subject is given in Table I. 


\section{Table I about here}

Responses to the open questions regarding why pupils wanted to change class or set were analysed using an iterative process of categorisation based on a seven stage process developed by Cooper and McIntyre (1993). The process involved: 1 . Reading a random sample of scripts; 2. Identifying points of similarity and difference among the transcripts in relation to the research questions; 3 . Generating theories (on the basis of 2) describing emergent answers to the research questions; 4. Testing theories against a new set of transcripts; 5. Testing new theories against transcripts already dealt with; 6. Carrying all existing theories forward to new transcripts; 7 . Repeating the above process until all data had been examined and all theories tested against all data. Categorisations were checked by a second judge by randomly sampling from the questionnaire output. The size of the data base precluded independent categorisation of all statements.

In reporting the findings percentages are based on the proportions of pupils responding to each question. As not all pupils wanted to change class or set the sample size varies.

\section{Findings}

\section{Satisfaction with class or grouping placements}

\section{Mathematics}

Of the total sample of 8317 pupils, information on class or set placement in mathematics was available for 6578 pupils (79\%). Of these 6039 were taught in sets in Year 9 and 539 were 
taught in mixed ability classes. In some cases, on the basis of the available data, it was not possible to rigorously designate pupils as belonging to top, middle or bottom sets. Where this was the case the data for those pupils were omitted. 5805 pupils were categorised as being in a top, middle or bottom set. $1635(28 \%)$ were recorded as being in a top set, $3143(54 \%)$ in a middle set and $1028(18 \%)$ in a bottom set.

Satisfaction with current grouping - A sizeable proportion of pupils were not happy with the set or class that they were in and wanted to move to a different set. The largest proportion wanting to change class or set across the subjects was in mathematics $(38 \%)$. There were also gender differences, $40 \%$ of males were likely to want to change class or set as opposed to $35 \%$ of females $\left(\mathrm{x}^{2}=15 \cdot 23, \mathrm{df}=1, \mathrm{p}=.0001\right)$. Satisfaction with grouping placement was influenced by the type of school that the students were in. $39 \%$ in set schools wished to change class or set, $43 \%$ in partially set schools and $31 \%$ in mixed ability schools $\left(\mathrm{x}^{2}=\right.$ $65.94, \mathrm{df}=2, \mathrm{p}=.0001)$. Those in the bottom set were also more likely to want to change set $(62 \%)$ than those in the middle $(45 \%)$ or top groups $(16 \%)\left(x^{2}=610.47, d f=2, p=.0001\right)$.

Preferred set - Of the $38 \%$ of pupils who wanted to change class or set, just over a quarter $(28 \%, 666)$ wanted to be in the top set and almost half $(49 \%, 1169)$ in another higher set. Overall, $77 \%$ of those pupils who wanted to move wanted to be in a higher set. $17 \%$ (421) wanted to move down to a lower set, $2 \%$ (46) wanted to be in a parallel class or set. For pupils wanting to be in a parallel set, the desire for change was not related to concerns about sets per se but other social or teaching/learning reasons.

The boys in particular wanted to be in the top $(33 \%, 440)$ or a higher set $(50 \%, 664)$. Only $13 \%$ (169) wanted to move to a lower set. In contrast, only $21 \%$ (226) of girls wanted to be in 
the top set, $47 \%$ (505) wanted to be in another higher set while $24 \%$ (252) wanted to move to a lower set $\left(x^{2}=78.17, d f=4, p=.0001\right)$.

The type of school attended was also a significant influence on which set pupils wanted to move to. In the mixed ability schools, where setting was more limited, more pupils wanted to move into the top set, $37 \%$ (258) as opposed to $25 \%$ (225) in the partially set schools and $23 \%$ (202) in the set schools. In the set $(56 \%, 495)$ and partially set schools $(51 \%, 462)$ more pupils wished to move to a higher set but not the top set $\left(x^{2}=88.02, \mathrm{df}=8, \mathrm{p}=.0001\right)$. There was little difference between school type in the overall percentage of pupils who wished to move down a set with a range from $16.7 \%$ to $18.4 \%$.

By far the strongest indicator of which set pupils wanted to move to was current set or class placement. Table II sets out the percentages of students wanting to move to particular sets in relation to their current set placement for maths, science and English. Because each school had different levels of setting three overall groups were created, top, middle, and bottom. These were based on pupil numbers with $25 \%$ of pupils being allocated to each of the top and bottom categories with $50 \%$ in the middle category. In some cases pupils who were classed as already being in a top set reported wanting to move to another top set as, in their school, more than one set was classified as being a 'top' set. For instance they may have been in Set 2 of 12 and wanted to move to Set 1.

In mathematics, more pupils who were in middle sets wanted to move to the top sets $(35 \%)$ than those already in the top sets $(11 \%)$ or bottom sets $(15 \%)$. The greatest proportion wanting to move to a higher placement were in the bottom sets $(79 \%)$ followed by the middle sets $(48 \%)$. Of those who wished to change set in the top sets $82 \%$ reported that they would 
like to move to a lower set as opposed to $13 \%$ in the middle sets and $2 \%$ in the bottom sets $\left(x^{2}=1034.44, \mathrm{df}=8, \mathrm{p}=.0001\right)$.

\section{Table II about here}

\section{Science}

Overall, data relating to set or class placement in science were available for 6191 pupils (74\%). Of these 1323 were in top sets (21\%), 2157 were in middle sets $(35 \%), 804$ were in bottom sets (13\%) and 1907 were in mixed ability groups (31\%).

Satisfaction with current grouping - 30\% (1819) of pupils who responded to the question, indicated a desire to change groups. More boys $(32 \%, 1003)$ wanted to change class or set than girls $(28 \%, 816)$. These differences were statistically significant $\left(x^{2}=8.01, d f=1, p=\right.$ $.005)$. In the set schools, $35 \%$ (776) of pupils wanted to change set in science as opposed to $32 \%(648)$ in the partially set schools and $23 \%(457)$ in the mixed ability schools $\left(x^{2}=82.14\right.$, $\mathrm{df}=2, \mathrm{p}=.0001)$. The greatest proportion of students wanting to change set were in the bottom set $(54 \%, 430)$ with $41 \%(858)$ in the middle sets and only $11 \%$ in the top set (143) $\left(x^{2}=651.34, d f=3, p=.0001\right)$.

Preferred set - Of the $30 \%$ who wanted to change set in science, almost a third $(31 \%, 566)$ wanted to be in the top set and approximately two fifths $(41 \%, 744)$ in another higher set. Overall $72 \%$ of those wanting to move set wanted to move up. Only $14 \%$ (252) wanted to move down, while $8 \%$ (139) wanted to move to a parallel set and 6\% (115) wanted to move to another unspecified group. 
More boys $(37 \%, 369)$ than girls $(24 \%, 197)$ wanted to be in the top set, although the numbers wanting to be in another higher group were very similar (boys $42 \%$, girls, $41 \%$ ). More girls wanted to be in a lower set $(19 \%, 155)$ than boys $(10 \%, 97)\left(x^{2}=59.8, d f=4, p\right.$ $=.0001)$.

The proportion of pupils wishing to change set in science also varied by type of school. In science the pattern differed from mathematics. Here the greatest proportion of pupils wanting to move into the top set was in the partially set schools $(37 \%, 240)$. In the set schools more pupils wanted to be in another higher set $(53 \%, 414)$ rather than the top set $(27 \%, 214)$. The smallest proportion wanting to move into the top set was in the mixed ability schools $(31 \%$, $135)$ as was the smallest proportion wanting to move down $(11 \%, 47)$. In the mixed ability schools, $27 \%$ of pupils wanted to move to parallel $(27 \%, 121)$ or other $(15 \%, 67)$ sets or classes. In the set and partially set schools the proportion of those wanting to be in a lower set was $15 \%$. Only $1 \%$ (7) wanted to move a parallel set or class. These differences were statistically significant $\left(\mathrm{x}^{2}=486.18, \mathrm{df}=8, \mathrm{p}=.0001\right)$.

As in mathematics the greatest proportion wanting to move to a higher set were in the bottom sets $(80 \%, 344)$, followed by the middle sets $(41 \%, 351)$. Of those in the middle sets $43 \%$ (369) wanted to move into the top set. Of those in the bottom sets $15 \%$ (62) wanted to move in to the top set. These differences were statistically significant $\left(x^{2}=1605.78, \mathrm{df}=12, \mathrm{p}=\right.$ $.0001)$. Of those being taught in mixed ability classes $46 \%$ (103) wanted to move to another parallel class (see Table II). 


\section{English}

Overall, data relating to grouping in English were available for 6420 pupils. Of these 863 were in a top set (13\%), 1427 were in middle sets (22\%), 479 were in bottom sets (7\%) and 3651 were taught in mixed ability groups $(57 \%)$.

Satisfaction with current grouping - Overall, 23\% (1343) of students who responded to the question wanted to change class in English. As in the other subjects more boys $(25 \%, 708)$ were dissatisfied than girls $(22 \%, 586)$. These differences were statistically different $\left(x^{2}=\right.$ $6.75, \mathrm{df}=1, \mathrm{p}=.005)$. There were also differences between type of school. The greatest proportion wishing to change set were in the set schools $(30 \%, 647)$ followed by the partially set schools $(25 \%, 446)$. The smallest number were in the mixed ability schools $(14 \%, 250)$. These differences were significantly different $\left(x^{2}=131.2, \mathrm{df}=2, \mathrm{p}=.0001\right)$. As with the other subjects the greatest proportion wanting to change were in the bottom sets $(50 \%, 229)$, followed by the middle sets $(37 \%, 508)$ with the smallest number being in the top sets $(12 \%$, 99). These differences were statistically significant $\left(x^{2}=455.49, \mathrm{df}=3, \mathrm{p}=.0001\right)$.

Preferred set - Of the $26 \%$ wishing to change set in English, almost a third $(30 \%, 382)$ wanted to be in the top set and just over a third $(35 \%, 438)$ in another higher set. Overall, $12 \%(153)$ wanted to move to a lower set, $13 \%$ (163) to a parallel set, and $10 \%$ (122) to another unspecified group.

As in the other subjects, more males than females wanted to move into the top set (boys 33\%, 230; girls 27\%, 152) or another higher set (boys, 39\%, 267; girls 30\%, 152). Girls were also more likely to want to move down a set $(17 \%, 97)$ than boys $(8 \%, 56)$. These differences 
were statistically significant $\left(x^{2}=41.09, \mathrm{df}=4, \mathrm{p}=.0001\right)$. There were no gender differences in expressed wish to move to another parallel class or set (13\%).

With regard to type of school, the pattern in English was very similar to science. In the mixed ability schools the greatest proportion of pupils wanted to move to a parallel $(38 \%, 89)$ or other $(30 \%, 69)$ set or class. In the partially set schools $69 \%$ (295) wanted to move up, 39\% (165) to the top set. In the set schools $78 \%$ (498) wanted to move up, almost half of these to another higher set $(49 \%, 315)$. These differences were statistically significant $\left(x^{2}=414.48\right.$, $\mathrm{df}=8, \mathrm{p}=.0001)$

Those in the bottom sets were again more likely to want to move into the top set $(13 \%, 29)$ or another higher set $(82 \%, 187)$. In the middle sets $46 \%$ (232) wanted to move into the top set and 44\% (223) into another higher set. In the top set, of those wanting to change set, $77 \%$ (78) wanted to move down to a lower set. Of pupils in mixed ability classes $49 \%$ (137) indicated that they would like to move to another parallel class. These differences were statistically significant $\left(\mathrm{x}^{2}=1269.27, \mathrm{df}=12, \mathrm{p}=.0001\right)$.

\section{Reasons for wanting to change set or class}

The reasons for wanting to change set or class were broadly similar across the three subject areas, although different categories were emphasised in each of the three subjects. Tables III, IV and V set out the reasons given with example quotes taken from the questionnaires. Table III sets out the categories relating specifically to learning, Table IV those relating to motivation, future prospects and status, and Table $\mathrm{V}$ those related to teaching, friendship and 
behaviour. Table VI sets out the frequency with which each reason was given for each subject domain.

\section{Tables III, IV V and VI about here}

Reasons for wanting to change set or class in mathematics - The main reason for pupils wanting to change set in maths was related to learning: to do harder (27\%), or easier work $(15 \%)$ or work at a quicker pace $(1.5 \%)$. For some students issues relating to status, their futures and motivation were reported. Status was cited by $11 \%$ and $7 \%$ indicated that they thought that they were clever enough to be in a higher set. Other reasons given were examination results (3\%), improving attainment (3\%), wanting to learn more (2\%), and wanting a better education (2\%). A small percentage cited the personal qualities of the teacher (4\%) and the teacher's skills (2\%), while $2 \%$ referred to the poor behaviour of classmates (2\%) and $4 \%$ wanting to be with friends. $8 \%$ indicated a combination of reasons. Table V outlines the reported reasons for wanting to change set across all three subject domains.

Reasons for wanting to change set or class in science - The main reasons given for wanting to change set in science were similar to those given for mathematics and overwhelmingly related to the level of work. $22 \%$ wanted more difficult work, $11 \%$ easier work, $7 \%$ wanted to be in a higher status group or thought that they were clever enough to be moved up. A higher proportion in science than maths wanted to be with friends $(9 \%) .4 \%$ gave as their reason for wanting to move teacher qualities or the poor behaviour of classmates. $8 \%$ cited a combination of reasons. 
Reasons for wanting to change set or class in English - The main reasons given for wanting to change set in English were again related to the level of work being set. 19\% wanted harder work, and $10 \%$ easier work. $8 \%$ gave status reasons, $7 \%$ felt that they were clever enough to move up into another set and $8 \%$ gave friendship reasons. In contrast with the other subjects, the personal qualities of the teacher seemed more important in English (8\%). A combination of reasons was cited by $9 \%$ of respondents.

\section{Discussion}

This large scale study undertaken with over eight thousand children in 45 secondary schools showed that a high proportion of pupils were unhappy with their set or class placement. In mathematics, where there was the highest level of ability grouping, over a third (38\%) of pupils were unhappy with their set or class placement; in science with moderate levels of ability grouping 30\%; and in English, where there was a higher proportion of mixed ability teaching, $23 \%$. This suggests that pupils are more satisfied with their class or set placement when they are taught in mixed ability classes. Further support for this hypothesis comes from a consideration of differences between the three types of school. There were much higher levels of dissatisfaction with class or set placement in the schools classified as setted (maths $39 \%$, science 35\%, English, 30\%) or partially set (maths 43\%, science 32\%, English 25\%) than the mixed ability schools (maths $31 \%$, science 23\%, English 14\%).

Boys wished to change class or set more often (maths 40, science, 32, English, 25) than girls (maths 35\%, science 28\%, English 22\%), although this may be explained by the greater number of boys in the lower ability groups. Girls were more likely to wish to move down a set and boys more frequently made reference to status issues supporting Boaler's (1997b, 
2000) findings. Pupils were very aware of the negative connotations associated with being in a low set but were equally aware of the pressures of being in the top set. Some reported wanting to change set to be 'average'. This may indicate a need to fit in and be accepted by peers, where pupils do not value attaining the very highest academic levels, even though this may represent the institutional culture of the staff. Some support for this comes from the evidence that in setted and partially set schools more pupils wished to move to a higher but not necessarily the top set.

Unsurprisingly, across all subjects, more pupils in the bottom sets (maths 62\%, science, 54\%, English 50\%) wished to change set than those in the middle (maths, $45 \%$, science $41 \%$, English $37 \%$ ) or top sets (maths 16\%, science 11\%, English 12\%). Most pupils wanted to move to a higher set, although there were some exceptions to this. The reasons given for wanting to change set were overwhelmingly related to learning. For many pupils there was a mismatch between the work set and what they perceived was appropriate. Most felt the work that they were given was too easy, although some pupils, particularly in the top sets wanted to move down to have work which was easier. The reasons given strongly suggested that pupils wanted to fulfil their educational potential and maximise their future opportunities. Status reasons were reported less frequently than those relating to learning and motivation. Very few pupils reported social reasons for wishing to change class or set. Overall, pupils seemed to be adopting a mastery approach to learning rather than having performance goals (Ames \& Ames, 1992; Dweck and Leggett, 1998; Nicholls, 1989). They were focused on their own learning and understanding to a greater extent than attaining a higher status than their peers by being in a higher set. 
There were differences between subjects in the extent to which pupils wished to change sets. The greatest dissatisfaction with set placement was in mathematics, where setting was most frequently and rigorously deployed. This appears to be because the majority of teachers of mathematics believe that mathematics needs to be taught in groups of similar attainment because work builds on prior knowledge (Hallam \& Ireson, 2003), although the evidence suggests that there are no systematic differences in attainment whether pupils are taught in ability grouped or mixed ability classes (Ireson et al., 2002b; in press). The fewest indications of preferences to move between sets or classes were in English where most classes were taught in mixed ability groups, English teachers tending to view their subject as suitable for mixed ability teaching in part because differentiation can be by outcome (Hallam \& Ireson, 2003). For pupils in mixed ability classes there would have been no benefit to changing class in relation to the level of work set. Choices related to social reasons (to be with friends) or to have a different teacher. More pupils in English mentioned the personal qualities of the teacher as a reason for moving class. This may reflect the predominance of mixed ability teaching, the nature of the teaching methods adopted, or the subject's creative underpinnings which perhaps make the personal characteristics of the teacher more important in relation to the extent to which lessons are enjoyable. This, to date, is a relatively unexplored area.

Can we draw any conclusions regarding school grouping practices from these findings? This depends on whether we believe that we can trust pupils to accurately assess whether the work that they are set is at an appropriate level. Some may argue that teachers rather than pupils are the best judge of this. What emerges clearly from the findings is that for a substantial number of pupils there is a mismatch between their perceptions of what is an appropriate level of work and those of their teachers. This presents a serious issue for schools. While the findings indicate that the greatest mismatches occur in setted groups this may be an artefact of the research 
context. The only available option for moving to a different class for pupils taught in mixed ability groups was another mixed ability class offering no distinctive change in the level of work set. Because of this the findings cannot be taken to indicate that pupils taught in mixed ability classes felt that the work was set at an appropriate level, neither can they be taken to indicate that it was not.

Given that there are no systematic differences in overall attainment between pupils taught in mixed ability or setted classes the findings could be interpreted to support the case for mixed ability teaching to be adopted in all subjects (Ireson et al., 2002b; in press). In mixed ability classes teachers tend to differentiate work less (Hallam and Ireson, 2003) and teach at a wholeclass level to an 'imaginary' average child (Wragg, 1984). Evidence from international comparisons suggests that where there is less differentiation between schools and classes educational inequality is reduced (Green and Wiborg, 2004). However, at secondary level the majority of pupils report preferring ability grouping structures. The reason they give is that ability grouping enables work to be set at an appropriate level (Hallam \& Ireson, submitted). The current findings indicate that when ability grouping structures are in place, for a substantial proportion of pupils, work is perceived to be too difficult or, more commonly, too easy. If pupils moved freely between ability groups this issue might be resolved but the evidence from the pupils in this study (Ireson et al, 2002a) and research cited in the introduction to this paper suggests that this is generally not the case.

Given the limitations of ability grouped and mixed ability classes, perhaps we should explore other systems which offer more flexibility and enable students to progress in each subject at the pace which they find facilitates their understanding. Modular systems which operate across different age groups but are framed within particular levels of expertise can offer 
pupils choice and the opportunity to mix academic and vocational areas of study. They also enable specific levels of attainment to be set, achieved and documented as students are ready to take them, rather than at fixed points in time. The development of expertise in each subject domain set out through a series of levels, as is currently the case in graded music examinations, could provide a continuous record of progress from primary school through to degree level and beyond. This would enhance motivation and provide the real prospect of all students being able to demonstrate what they could do.

Another approach, which could operate alongside a modular system, is that of personalised systems of instruction. These, based on mastery learning (Bloom, 1976) have long been demonstrated to work successfully in the USA. The most common is the Personalised System of Instruction sometimes known as the Keller Plan (Keller, 1968). This involves establishing unit objectives for a course of study and developing tests for each unit. Students choose when to take a test and may re-sit it as often as they wish until they achieve a passing score. Students typically work on self-instructional materials and/or with peers to master the course content. Classes are given to supplement rather than guide the learning process. The system is extremely effective in raising standards with a very high proportion of students achieving the highest grades. This type of system has generally not been adopted in the UK, although some on-line learning programmes are based on these principles. However, an individualised programme known as school based flexible learning has shown considerable promise in geography teaching in the UK (Hughes, 1993). Pupils learn through independent study supervised through small group tutorials. The students are gradually shaped into working in this way over the period of their secondary education beginning with small steps in year 7 to much greater independence of working in year 11. The system has proved very successful, comparisons with parallel classes being taught in the same school by more traditional 
methods showing that over a four year period, the percentage of pupils gaining a grade $\mathrm{A}$ to $\mathrm{C}$ in GCSE geography using flexible learning rose form $41 \%$ to $85 \%$ and using traditional methods from $16 \%$ to $59 \%$. Pupils taught using the flexible learning system also had consistently better results in geography than in their other GCSEs. Pupils and their parents reported enhanced motivation, greater effort and increased work. The students indicated that this was the result of being given greater responsibility, independence and choice; being able to work at their own pace; not having to go over things they already knew; and having access to individual help when they needed it. Where raising attainment is high on the political agenda, and policy is claimed to be evidence based it is difficult to understand why these approaches are not being considered and piloted.

\section{Acknowledgements}

We would like to thank the staff and pupils in all the participating schools for their help in this project, which was made possible by funding from the Economic and Social Research Council and Sarah Hack and Helen Clark, the project research officers, for their assistance in collecting and entering the data. We would also like to thank the reviewers of the paper for their helpful comments which greatly improved the quality and clarity of the paper.

\section{References}

Ames C. \& Ames, A. (1992) Classrooms: goals, structures and student motivation, Journal of Educational Psychology, 84(3), pp. 261-271.

Barker Lunn, J.C. (1970) Streaming in the Primary School (Slough, NFER) 
Benn, C. \& Chitty, C. (1996) Thirty years on: is comprehensive education alive and well or struggling to survive? (London, David Fulton Publishers)

Bloom, B.S. (1976) Human characteristics and school learning (New York, Pantheon).

Boaler, J. (1997a) Setting, social class and the survival of the quickest, British Educational Research Journal, 23, pp. 575-595.

Boaler, J. (1997b) When even the winners are losers: evaluating the experiences of 'top set' students, Journal of Curriculum Studies, 29, pp. 165-182.

Boaler, J. (1997c) Experiencing school mathematics: teaching styles, sex and setting (Buckingham, Open University Press).

Boaler, J., Wiliam, D., \& Brown, M. (2000) Experiences of ability grouping -disaffection, polarisation and the construction of failure. British Educational Research Journal, 28(5), pp. 631-648.

Burgess, R.G. (1986) Education, Schools and Society ( London, Batsford).

Ceci, S.J. (1990) On Intelligence.... More or Less: A biological treatise on intellectual development (Englewood Cliffs, Prentice Hall). 
Cicourel, A. \& Kitsuse, J. (1963) The educational decision makers (Indianapolis, The Bobbs Merrill Company)

Commission for Racial Equality (1992) Set to fail? Setting and banding in secondary schools, (London, Commission for Racial Equality).

Cooper, P., \& McIntyre, D. (1993) Commonality in teachers' and pupils' perceptions of effective classroom learning. British Journal of Educational Psychology, 63, pp. 381-399.

Davies, J., Hallam, S, \& Ireson, J. (2003) Ability groupings in the primary school: issues arising from practice, Research papers in Education, 18(1), pp. 45-60.

Dentzer, E., \& Wheelock, A. (1990) Locked in/locked out: Tracking and placement in Boston public schools (Boston, MA., The Massachusetts Advocacy Center).

Devine, D. (1993) A study of reading ability groups: primary school children's experiences and views. Irish Educational Studies, 12, pp. 134-42.

Dreeben, R. \& Barr, R. (1988) Classroom composition and the design of instruction, Sociology of Education, 61, 129-142.

Dweck C.S. \& Leggett, E.L. (1998) Self-theories and goals: A social-cognitive approach to motivation and personality, Psychological Review, 95(2), pp. 256-273. 
Gillborn, D. \& Youdell, D. (2000) Rationing education: policy, practice, reform and equity. (Buckingham, Open University Press).

Green, A. \& Wiborg, S. (2004) Comprehensive schooling and educational inequality: An international perspective. In M. Benn \& C. Chitty (Eds) A tribute to Caroline Benn: Education and Democracy (pp. 204-216) London: Continuum

Hallam, S. (2002) Ability Grouping in Schools: a Literature Review (Institute of Education, University of London)

Hallam, S. \& Ireson, J. Secondary school pupils' preferences for different types of structured grouping practices (submitted to the British Educational Research Journal).

Hallam, S. \& Ireson, J. (2003) Secondary School Teachers' Attitudes to and Beliefs about Ability Grouping, British Journal of Educational Psychology, 73, 343-356.

Hallam, S., Ireson, J. \& Davies, J., (2004) Primary School Pupils' Experience of Different Types of Grouping in Schools, British Educational Research Journal, 30(4), pp. 515-534.

Harlen, W. \& Malcolm, H. (1997) Setting and streaming: a research review (Using Research Series 18) (Edinburgh, SCRE).

Hughes, M. (1993) Flexible learning: Evidence examined (Stafford, Network Educational Press). 
Ireson, J. \& Hallam, S. (2001) Ability grouping in education (London, Sage).

Ireson, J., Clark, H. \& Hallam, S. (2002a) Constructing Ability Groups in Secondary Schools: issues in practice, School Leadership and Management, 22(2), 163-176.

Ireson, J. Hallam, S., Hack, S., Clark, H. \& Plewis, I. (2002b) Ability Grouping in English Secondary Schools: Effects on Attainment in English, Mathematics and Science, Educational Research and Evaluation, 8(3), pp. 299-318.

Ireson, J., Hallam, S., \& Hurley, C. (in press) What are the effects of ability grouping on GCSE attainment? British Educational Research Journal.

Ireson, J., Hallam, S. \& Hurley, C. (in press) Pupils' relationships with school: does ability grouping make a difference? British Journal of Educational Psychology

Ireson, J., Hallam, S., \& Plewis, I. (2001) Ability grouping in secondary schools: Effects on pupils' self-concepts, British Journal of Educational Psychology, 71, pp. 315-326.

Jackson, B. (1964) Streaming: an education system in miniature (London, Routledge and Kegan Paul.

Keller, F.S. (1968) Goodbye teacher, Journal of Applied Behavioural Analysis, 1, pp 79-89.

Marsh, H.W. (1990) Self Description Questionnaire Manual (Sydney, University of Western Sydney). 
Neave, G. (1975) How they fared: The impact of the comprehensive school on the university. (London, Routledge and Kegan Paul)

Nicholls, J.G. (1989) The competitive ethos and democratic education (Cambridge, MA, Cambridge University Press)

Oakes, J. (1985) Keeping track: How schools structure inequality (New Haven, Yale University Press).

Oakes, J., Slevin, M., Karoly, L. \& Guiton, G. (1992) Educational match making: academic and vocational tracking in comprehensive high schools (Santa Monica, RAND).

Office for Standards in Education (1998) Setting in primary schools: A report from the Office of Her Majesty's Chief Inspector of Schools. (London, Ofsted).

Pallas, A.M., Entwisle, D.R., Alexander, K.L. \& Stluka, M.F. (1994) Ability grouping effects: instructional, social of institutional? Sociology of Education, 67(1), pp. 27-46.

Peak, B. \& Morrison, K. (1988) Investigating banding origins and destinations in a comprehensive school, School Organisation, 8(3), pp. 339-349.

Reuman, D.A. (1989) How social comparison mediates the relation between ability-grouping practices and students' achievement expectancies in mathematics, Journal of Educational Psychology, 91, pp.178-189. 
Rist, R. (1970) Student social class and teacher expectations: the self-fulfilling prophecy in ghetto education, Harvard Educational Review, 40, pp. 411-451.

Sandven, J. (1971) Causes of lacking a sense of well-being in school. Scandinavian Journal of Educational Research, 15(1), pp. 21-60.

Sukhnandan, L., \& Lee, B. (1998) Streaming, setting and grouping by ability (Slough, National Foundation for Educational Research).

Taylor, N. (1993) Ability grouping and its effect on pupil behaviour: A case study of a Midlands comprehensive school, Education Today, 43(2), pp. 14-17.

Thompson, D. (1974) Non-streaming does make a difference, Forum, 16, pp. 45-49.

Tomlinson, S. (1987) Curriculum option choices in multi-ethnic schools In B. Troyna (Ed) Racial inequality in Education. (London, Tavistock)

Troman, G. (1988) Getting it right: selection, setting in a 9-13 years middle school, British Journal of Sociology of Education, 9(4), pp. 403-22.

Troyna, B. (1992) Ethnicity and the organisation of learning groups: a case study, Educational Research, 34(1), pp. 45-55. 
Troyna, B., \& Siraj-Blatchford, I. (1993) Providing support or denying access? The experiences of students designated as ESL and SN in a multi-ethnic secondary school, Educational Review, 45(1), pp. 3-11.

Vanfossen, B.E., Jones, J.D., \& Spade, J. Z. (1987) Curriculum tracking and status maintenance, Sociology of Education, 60, April, pp. 104-122.

Wilson, G. (2000) The effects of season of birth, sex and cognitive abilities on the assessment of special educational needs, Educational Psychology, 20(2), pp. 153-166.

Winn, W. \& Wilson, A.P. (1983) The affect and effect of ability grouping, Contemporary Education, 54, pp. 119-125.

Wragg, E. C. (1984) (ed) Classroom Teaching Skills: the Research Findings of the Teacher Education Project. London: Routledge

Wright, C. (1987) Black students - white teachers. In B. Troyna (Ed) Racial inequality in Education. (London, Tavistock). 
Table I: Number of schools adopting setting in each subject and strength of setting scale

\begin{tabular}{|l|l|l|l|l|}
\hline & & English & Mathematics & Science \\
\hline $\mathbf{0}$ & $\begin{array}{l}\text { Mixed ability in } \\
\text { years 7-9 }\end{array}$ & 20 & 5 & 11 \\
\hline $\mathbf{1}$ & Set in year 9 only & 4 & 3 & 5 \\
\hline $\mathbf{2}$ & $\begin{array}{l}\text { Set in years 8 and } \\
9\end{array}$ & 6 & 7 & 13 \\
\hline $\mathbf{3}$ & $\begin{array}{l}\text { Set in years 7-9, } \\
\text { year 9 broadly set }\end{array}$ & 3 & 1 & 2 \\
\hline $\mathbf{4}$ & $\begin{array}{l}\text { Set in years 7-9, } \\
\text { year 9 rigorously } \\
\text { set }\end{array}$ & 12 & 29 & 14 \\
\hline
\end{tabular}


Table II: Preferred set to move to by current set placement

\begin{tabular}{|c|c|c|c|c|c|}
\hline \multirow[t]{2}{*}{$\begin{array}{l}\text { Current set } \\
\text { placement }\end{array}$} & \multicolumn{5}{|c|}{$\begin{array}{l}\text { Mathematics: preferred set to move to } \\
\qquad\left(\mathrm{x}^{2}=1034.44, \mathrm{df}=8, \mathrm{p}=.0001\right)\end{array}$} \\
\hline & Top & Other higher & Lower & Parallel & $\begin{array}{l}\text { Other (not } \\
\text { stated as top, } \\
\text { higher, lower } \\
\text { or parallel) }\end{array}$ \\
\hline Top sets & $11 \%(31)$ & $2 \%(5)$ & $82 \%(222)$ & $2 \%(4)$ & $3 \%(9)$ \\
\hline Middle sets & $35 \%(495)$ & $48 \%(673)$ & $13 \%(181)$ & $1 \%(13)$ & $3 \%(40)$ \\
\hline Bottom sets & $15 \%(96)$ & $79 \%$ (496) & $2 \%(15)$ & $1 \%(5)$ & $3 \%(20)$ \\
\hline Overall & $27 \%(622)$ & $51 \%(1174)$ & $18 \%(418)$ & $1 \%(22)$ & $3 \%(69)$ \\
\hline $\begin{array}{l}\text { Current set } \\
\text { placement }\end{array}$ & \multicolumn{5}{|c|}{$\begin{array}{l}\text { Science: preferred set to move to } \\
\left(\mathrm{x}^{2}=1605.78, \mathrm{df}=12, \mathrm{p}=.0001\right)\end{array}$} \\
\hline Top sets & $9 \%(13)$ & $3 \%(4)$ & $82 \%(122)$ & $3 \%(5)$ & $3 \%(5)$ \\
\hline Middle sets & $43 \%(369)$ & $41 \%(351)$ & $11 \%(99)$ & $3 \%(22)$ & $3 \%(26)$ \\
\hline Bottom sets & $15 \%(62)$ & $80 \%$ (344) & $2 \%(7)$ & $1 \%(4)$ & $3 \%(11)$ \\
\hline Mixed ability & $20 \%(44)$ & $4 \%(9)$ & $3 \%(6)$ & $46 \%$ (103) & $27 \%(61)$ \\
\hline Overall & $29 \%(488)$ & $43 \%(708)$ & $14 \%(234)$ & $8 \%(134)$ & $6 \%(103)$ \\
\hline $\begin{array}{l}\text { Current set } \\
\text { placement }\end{array}$ & \multicolumn{5}{|c|}{$\begin{array}{l}\text { English: preferred set to move to } \\
\left(\mathrm{x}^{2}=1269.27, \mathrm{df}=12, \mathrm{p}=.0001\right)\end{array}$} \\
\hline Top sets & $10 \%(10)$ & $2 \%(2)$ & $77 \%(78)$ & $1 \%(1)$ & $10 \%(10)$ \\
\hline Middle sets & $46 \%(232)$ & $44 \%(223)$ & $8 \%(41)$ & $.2 \%(1)$ & $3 \%(13)$ \\
\hline Bottom sets & $13 \%(29)$ & $82 \%(187)$ & $2 \%(5)$ & $1 \%(2)$ & $2 \%(4)$ \\
\hline
\end{tabular}




\begin{tabular}{|l|l|l|l|l|l|}
\hline Mixed ability & $16 \%(46)$ & $5 \%(13)$ & $3 \%(9)$ & $49 \%(137)$ & $27 \%(77)$ \\
\hline Overall & $28 \%(317)$ & $38 \%(425)$ & $12 \%(133)$ & $13 \%(141)$ & $9 \%(104)$ \\
\hline
\end{tabular}


Table III: Reasons for wanting to change set or class (learning)

\begin{tabular}{|l|l|}
\hline Category & Example quotes \\
\hline To do harder work & $\begin{array}{l}\text { I am in set } 9 \text { for maths and would like to change to } 6 \text { or } 7 \text { because the work is too easy. } \\
\text { In the bottom class the work is too simple. } \\
\text { I would like to try harder work. }\end{array}$ \\
\hline $\begin{array}{l}\text { To do easier work at an } \\
\text { appropriate level and } \\
\text { pace with more support }\end{array}$ & $\begin{array}{l}\text { I am in set } 1 \text { for English. I would like to move to set } 2 \text { because the work is a bit easier. } \\
\text { Things are explained in more detail and you go over things that you aren't expected to } \\
\text { know. } \\
\text { The work is easier and there is less pressure and high expectations. }\end{array}$ \\
\hline $\begin{array}{l}\text { The pace of work is } \\
\text { inappropriate }\end{array}$ & $\begin{array}{l}\text { I had a good teacher and I understood. She explained it more and the group was } \\
\text { slower. } \\
\text { The teacher goes through the work too quickly and I don't understand. } \\
\text { I want to go faster. } \\
\text { My class is too slow and I am not learning anything. }\end{array}$ \\
\hline $\begin{array}{l}\text { There will be people of } \\
\text { the same intelligence in } \\
\text { the group }\end{array}$ & $\begin{array}{l}\text { More streaming produces more 'specialised ability'. } \\
\text { People that are around the same level. }\end{array}$ \\
\hline
\end{tabular}




\section{Table IV: Reasons for wanting to change set or class (motivation, future prospects and identity)}

\begin{tabular}{|c|c|}
\hline Status & $\begin{array}{l}\text { All the clever people go into this set and I guess deep down everyone wants to be } \\
\text { intelligent and get somewhere in life. } \\
\text { Because if you are in the top set then you are very good at maths and people are proud } \\
\text { to be at this level. } \\
\text { Ifeel like I am really crap at science as I am in set } 3 \text { of } 4 \text {. If I was in set } 2 \text { I would feel } \\
\text { much better. } \\
\text { Sets } 1 \text { or } 2 \text { are best. People in them are very clever. } \\
\text { It's the highest set in the year and teachers respect you. }\end{array}$ \\
\hline $\begin{array}{l}\text { I think I am clever } \\
\text { enough }\end{array}$ & $\begin{array}{l}\text { Because I feel that I am being held back from what I can achieve. } \\
\text { I know I can do the work. } \\
\text { Because I know I can do better. } \\
\text { I am too clever for the second set. } \\
\text { Because I am capable of being there. }\end{array}$ \\
\hline To prove my ability & $\begin{array}{l}\text { Because I would like to prove to myself that I can reach that standard. } \\
\text { Because then I know I'm smarter. }\end{array}$ \\
\hline $\begin{array}{l}\text { I want to improve my } \\
\text { attainment }\end{array}$ & $\begin{array}{l}\text { I would like to be in set } 1 \text { for English because there is more chance of having a } \\
\text { successful future. } \\
\text { People in that set are really clever so you are more likely to do well. } \\
\text { I want to do well in science. } \\
\text { I want to show my full potential. } \\
\text { I would like to try for an A*. } \\
\text { I think I could do well and I want to get even better grades for harder work. } \\
\text { If I'm pushed a little more I can do really well in science. }\end{array}$ \\
\hline I want to learn more & $\begin{array}{l}\text { I want to learn a lot more things. } \\
\text { You learn more of the difficult things. }\end{array}$ \\
\hline $\begin{array}{l}\text { I want to get a better } \\
\text { education }\end{array}$ & $\begin{array}{l}\text { I want to get a better education. } \\
\text { Because there is better education and more opportunities. }\end{array}$ \\
\hline $\begin{array}{l}\text { My examination results } \\
\text { would be better }\end{array}$ & $\begin{array}{l}\text { Because it might help with my GCSEs. } \\
\text { In GCSEs you get put in for the higher paper. } \\
\text { So I can get more help and get a better mark. }\end{array}$ \\
\hline $\begin{array}{l}\text { I want to be able to get a } \\
\text { better job }\end{array}$ & $\begin{array}{l}\text { You need to be in a high set as maths is very important for getting a job. } \\
\text { Because I could get a better job. } \\
\text { There is more chance of getting a better job. }\end{array}$ \\
\hline $\begin{array}{l}\text { I am motivated to do } \\
\text { this }\end{array}$ & $\begin{array}{l}\text { Because it's a challenge. } \\
\text { I want to be the best student. } \\
\text { I want to have something to aim for. } \\
\text { I want to be a vet and I need this. } \\
\text { I want to be a pilot and I need maths. }\end{array}$ \\
\hline $\begin{array}{l}\text { It will be more } \\
\text { interesting in a higher } \\
\text { set }\end{array}$ & $\begin{array}{l}\text { The work is more fun and there is more practical work. } \\
\text { There is more variety in the work. } \\
\text { I get bored with repeating things over and over. }\end{array}$ \\
\hline $\begin{array}{l}\text { I enjoy the subject and } \\
\text { the work is more varied } \\
\text { in a higher set }\end{array}$ & $\begin{array}{l}\text { I really like English so I would like to be in a high set. } \\
\text { I am quite good in English and I would like to be able to do more creative writing. }\end{array}$ \\
\hline I want to be average & $\begin{array}{l}\text { Because it's average and its good not to be too smart, just in the middle. } \\
\text { Because if you are in a low set you are stupid and if you are in a high set you are a } \\
\text { boffin. } \\
\text { I just want to be like other people. }\end{array}$ \\
\hline
\end{tabular}




\section{Table V: Reasons for wanting to change set or class (teachers, friends and behaviour)}

\begin{tabular}{|l|l|}
\hline $\begin{array}{l}\text { The personal qualities } \\
\text { of the teacher }\end{array}$ & $\begin{array}{l}\text { I'd like to be with Miss X because she's funny. } \\
\text { The teacher lets you have a laugh. } \\
\text { The teacher is nice. } \\
\text { We have a 'wicked' teacher. } \\
\text { Because the teacher treats you more like an adult. }\end{array}$ \\
\hline Skills of the teacher & $\begin{array}{l}\text { Characteristics of preferred teachers } \\
\text { Because the teacher is good - that set read and watch videos a lot. } \\
\text { The teacher explains it well. } \\
\text { The teachers are good and listen. } \\
\text { The teachers are better and control the class better. } \\
\text { I want to get more done because the teachers are stricter. } \\
\text { Characteristics of non-preferred teachers } \\
\text { I don't think my teacher is a very good teacher. } \\
\text { I don't like my teacher and he doesn't get on with anyone in our class. He can't teach } \\
\text { to save his life. } \\
\text { My friends are in that group and I would be able to sit next to one of them. } \\
\text { I have no friends in my class. }\end{array}$ \\
\hline $\begin{array}{l}\text { T'm in a low set because I'm naughty when I am with my friends. } \\
\text { Because people in my set waste time and muck around. } \\
\text { Because when I am with friends I am easily distracted. } \\
\text { I would like to get on with my work and not have people mess about. } \\
\text { My class is too noisy. } \\
\text { Everybody is better behaved and we get more work done. }\end{array}$ \\
\hline classmates
\end{tabular}


Table VI: Frequency of reasons given for changing set or class by subject

\begin{tabular}{|c|c|c|c|}
\hline Reason & Mathematics & Science & English \\
\hline To do harder work & $27 \%(672)$ & $22 \%(403)$ & $19 \%(247)$ \\
\hline To do easier work & $15 \%(373)$ & $11 \%(203)$ & $10 \%(127)$ \\
\hline Status & $11 \%(264)$ & $7 \%(135)$ & $8 \%(103)$ \\
\hline I think I am clever enough & $7 \%(170)$ & $7 \%(132)$ & $7 \%(96)$ \\
\hline To be with friends & $4 \%(95)$ & $9 \%(169)$ & $8 \%(110)$ \\
\hline The personal qualities of the teacher & $4 \%(90)$ & $4 \%(84)$ & $8 \%(107)$ \\
\hline My examination results would be better & $3 \%(85)$ & $2 \%(41)$ & $2 \%(24)$ \\
\hline I want to improve my attainment & $3 \%(85)$ & $3 \%(55)$ & $3 \%(36)$ \\
\hline Poor behaviour of classmates & $2 \%(59)$ & $4 \%(67)$ & $3 \%(42)$ \\
\hline Skills of the teacher & $2 \%(57)$ & $3 \%(59)$ & $3 \%(36)$ \\
\hline I want to learn more & $2 \%(54)$ & $3 \%(60)$ & $3 \%(36)$ \\
\hline I want to get a better education & $2 \%(44)$ & $2 \%(32)$ & $2 \%(27)$ \\
\hline The pace would be quicker & $1.5 \%(37)$ & $2 \%(41)$ & $1.5(20)$ \\
\hline To prove my ability & $.9 \%(23)$ & $.5 \%(10)$ & $.6(8)$ \\
\hline I am motivated to do this & $.8 \%(21)$ & $1 \%(25)$ & $.8(36)$ \\
\hline I want to be average & $.8 \%(20)$ & $1 \%(18)$ & $.4(5)$ \\
\hline I want to be able to get a better job & $.7 \%(18)$ & $1 \%(21)$ & $.7(9)$ \\
\hline $\begin{array}{l}\text { There will be people of the same intelligence in } \\
\text { the group }\end{array}$ & $.7 \%(17)$ & $1 \%(25)$ & $1.5(20)$ \\
\hline I enjoy the subject & $.5 \%(12)$ & $2 \%(32)$ & $1 \%(16)$ \\
\hline It will be more interesting & $.4 \%(11)$ & $1 \%(20)$ & $2 \%(22)$ \\
\hline Combination & $8 \%(192)$ & $8 \%(156)$ & $9 \%(113)$ \\
\hline
\end{tabular}




\begin{tabular}{|l|c|c|c|}
\hline Other & $3 \%(75)$ & $4 \%(83)$ & $7 \%(89)$ \\
\hline Total responses & $2474(30 \%)$ & $1869(23 \%)$ & $1304(16 \%)$ \\
\hline
\end{tabular}

